\title{
THE ULTRAFILTRABLE CALCIUM OF HUMAN SERUM. I. ULTRAFILTRATION METHODS AND NORMAL VALUES ${ }^{1}$
}

\author{
By T. Y. TORIBARA, A. RAYMOND TEREPKA, AND PRISCILLA A. DEWEY \\ (From the Division of Pharmacology of the Department of Radiation Biology, and the Depart- \\ ment of Medicine, University of Rochester School of Medicine and Dentistry, \\ Rochester, N. Y.)
}

(Submitted for publication November 26, 1956; accepted January 24, 1957)

Since the demonstration by Rona and Takahashi in 1911 (1) that a considerable portion of the calcium present in the serum is not diffusible through a semi-permeable membrane, the various calciumfractions in the blood have been extensively studied. It is now recognized that calcium exists in the serum in three distinct forms. One of these, that calcium bound to proteins, comprises the nonultrafiltrable or non-diffusible portion of the serum calcium. The other two forms, ionic calcium and calcium complexed by such small anions as citrate, phosphate, and bicarbonate, are ultrafiltrable and diffusible.

Ionic calcium is generally considered to be the physiologically active component of the total serum calcium (20). Recently, however, it has been suggested (21) that the "biologically active" calcium fraction of serum is different from, and probably larger than, the total ionic calcium as determined by the frog heart technique (22), approaching the value for total ultrafiltrable calcium. In any event, a practical method for the routine measurement of actual ionic calcium has yet to be devised. Consequently, a great deal of effort has been directed toward the development of indirect methods for its determination in man. A variety of techniques has been described, but ultrafiltration methods have been most numerous because of practical and theoretical advantages over biological assays or dialysis techniques. In principle, all ultrafiltration procedures utilize some type of membrane of small pore size and some means of supplying filtration pressure.

The purpose of the present communication is to describe a technique for the ultrafiltration of hu-

1 This paper is based on work performed under contract with the United States Atomic Energy Commission at the University of Rochester Atomic Energy Project, Rochester, New York. man serum using a new, simple apparatus ${ }^{2}$ which eliminates most of the disadvantages of previous methods. Using this apparatus we have investigated the various factors which influence the ultrafiltrability of calcium in human serum and have determined the normal range in healthy human subjects. A subsequent paper will describe our findings in diseased states and under experimental conditions.

\section{METHODS}

Ultrafiltration apparatus and procedure. The apparatus used in this work has been described very briefly in a previous publication (23). It uses seamless cellophane tubing to contain the serum with a sintered glass support for the membrane and centrifugal force to supply the filtration pressure. Its principal advantages over other equipment are: 1) The atmosphere and the $\mathrm{pH}$ can be accurately controlled within the apparatus throughout the ultrafiltration period; 2) there is no source of metallic contamination; 3) membrane breakage is virtually eliminated; 4) the apparatus is easily constructed and can be used in an ordinary laboratory centrifuge; 5) filtration pressure can be controlled by varying centrifuge speed.

The ultrafiltration procedure was carried out in the following manner:

A strip of Visking Nojax Casing (size 24/32) about 9 inches long was soaked in distilled water for $10 \mathrm{~min}$ utes. It was wiped dry by drawing through a folded gauze sponge repeatedly until no water was visible. One end was knotted and the tubing was doubled (Figure 1) and pushed into the ultrafiltration tube with the knot up. The unknotted end was opened with a sharp instrument such as a scalpel blade or small spatula and inflated by blowing into it. For the present studies, $3 \mathrm{ml}$. of serum were pipetted directly into the open end of the bag. Care was taken to avoid contact between the wet

\footnotetext{
2 Made by sealing off the short end of a borosilicate glass straight sealing tube with coarse fritted disc (Corning No. 39570, 25-mm. diameter with $20-\mathrm{mm}$. disc), and adding a 6-mm. glass tube at an angle near the fritted disc (Figure 1). Complete apparatus is now available from Will Corporation, Rochester, New York.
} 


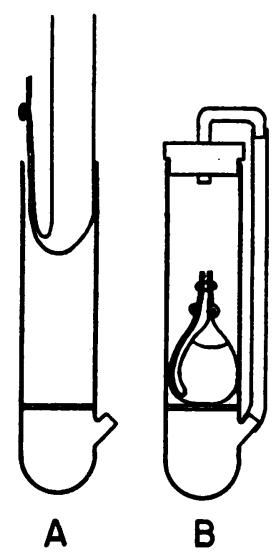

Fig. 1. The Apparatus Used for Ultrafiltration of SERUM

A. The apparatus containing the knotted and inflated Visking tubing prior to the introduction of the serum sample.

B. The apparatus closed and ready for centrifugation showing the serum filled ultrafiltration sac resting on the sintered glass support.

tip of the pipet and the cellophane tubing because such contact resulted in difficulty in removing the pipet. After the serum was introduced, the cellophane bag was collapsed, and the second end was knotted at about the same height as the first end. The two knotted ends were fastened together with a rubber band, and the bag was carefully pushed down into the apparatus far enough to permit insertion of the rubber stopper. To avoid tearing the bag, a blunt instrument, such as a stirring rod, was used to push adherent portions of the bag away from the glass. The apparatus was then flushed for 3 minutes with a 5 per cent $\mathrm{CO}_{2}-95$ per cent $\mathrm{O}_{2}$ mixture bubbled through isotonic saline and introduced through the side arm at the lower end of the apparatus. The apparatus was then closed by connecting the side arm to the glass tube in the rubber stopper at the top using Tygon tubing, thus assuring a constant atmosphere above and below the ultrafiltration sac throughout the ultrafiltration procedure (Figure 1). It was then placed in the largest cups (catalog No. 373) of an International Centrifuge, Size 2, or International Refrigerated Centrifuge, the cups having been fitted with the simple centering ring previously described (23) so that apparatus breakage was prevented while starting and stopping the centrifuge.

A temperature rise of about $8^{\circ} \mathrm{C}$ above the existing room temperature will occur inside the operating centrifuge in about 1 to 2 hours. To keep the temperature constant during ultrafiltration in the ordinary laboratory centrifuge, the latter was fitted with a copper coil. This was connected with Tygon tubing to the side-arm of a large glass U-tube. One arm of the U-tube was connected to the ordinary mixing-type water spigot and the other was fitted with a thermometer. Inlet water temperature was manually controlled by simply varying the amount of hot and cold water allowed to flow through the spigot into the U-tube. A thermometer was fitted into the center tachometer hole of the centrifuge and the temperature inside the centrifuge was kept constant by the adjustments in the inlet water temperature.

At $23^{\circ}$ or $37^{\circ} \mathrm{C}$, at least $0.5 \mathrm{ml}$. of a crystal-clear protein-free (24) ultrafiltrate was collected in 3 hours when centrifuged at $2,000 \mathrm{rpm}$, while at $10^{\circ} \mathrm{C}$ approximately double that time was necessary. If $5 \mathrm{ml}$. or more of serum were used, $1 \mathrm{ml}$. of ultrafiltrate could be obtained in approximately the same times. Variations in centrifuge speed between 1,500 and $2,500 \mathrm{rpm}$ do not affect the results obtained (24).

Determination of calcium. Calcium in both serum and ultrafiltrate was determined by a flame photometric technique using a Weichselbaum-Varney flame photometer. After protein removal (in the case of serum) the calcium was separated as the oxalate, re-dissolved, and read directly. A description of the method together with a thorough study of possible variables have already been reported (25).

Determination of $\mathrm{pH}$. A Beckman model $\mathrm{G} \mathrm{pH}$ meter was used for the $\mathrm{pH}$ measurements. In all instances, the $\mathrm{pH}$ of the serum remaining in the ultrafiltration sac was measured after the ultrafiltration was carried out. In several instances, $\mathrm{pH}$ values of both the ultrafiltrate and the unfiltered serum residue were determined. As would be expected where the atmosphere was maintained constant over the serum and ultrafiltrate, the $\mathrm{pH}$ values were the same. Generally, the value obtained was between 7.5 and 7.6 if the apparatus were allowed to return to room temperature (at which the equilibrium with 5 per cent $\mathrm{CO}_{2}-95$ per cent $\mathrm{O}_{2}$ mixture was carried out) and the $\mathrm{pH}$ measurement were then made.

Early in the present work it was noted that the $\mathrm{pH}$ tended to drift with time as the concentrated serum left in the ultrafiltration sac was being measured with a conventional asbestos-fibre calomel electrode. This was virtually eliminated, however, when a sleeve-type calomel electrode (Beckman No. 270-71) was used.

Collection of sample. Blood was collected with an ordinary syringe and a 20-gauge needle by venipuncture in the antecubital fossa. No precautions were taken to prevent loss of $\mathrm{CO}_{2}$ (see discussion under Effect of method of sample collection). The ultrafiltration procedure was carried out on the same day the samples were collected.

\section{RESULTS}

In expressing ultrafiltration results, some authors have used a corrected serum volume calculated from the estimated volume occupied by the proteins present. We have not used the correction but have applied the following definition to express our results :

$$
\begin{aligned}
& \% \text { Ultrafiltrable } \mathrm{Ca} \\
& \qquad=\frac{\mathrm{Mg} \cdot \mathrm{Ca} / 100 \mathrm{ml} \text {. ultrafiltrate }}{\mathrm{Mg} . \mathrm{Ca} / 100 \mathrm{ml} . \text { serum }} \times 100
\end{aligned}
$$


TABLE I

Results obtained with and without precautions for loss of $\mathrm{CO}_{2}$. Ultrafiltration temperature $23^{\circ} \mathrm{C}$

\begin{tabular}{|c|c|c|c|c|c|c|}
\hline \multirow[b]{2}{*}{ Sample } & \multirow[b]{2}{*}{ Mothod } & \multicolumn{2}{|c|}{ pH } & \multicolumn{3}{|c|}{ SERUM CALCIUS } \\
\hline & & Initial & Final & $\begin{array}{c}\text { Total } \\
\text { ag\% }\end{array}$ & $\begin{array}{c}\text { U1trafilterablo } \\
\text { mg }\end{array}$ & $\frac{\$}{\text { OLtrafilterable }}$ \\
\hline \multirow[t]{2}{*}{$\mathbf{R}$} & oil & 7.52 & 7.47 & 9.52 & 7.04 & 73.9 \\
\hline & plain & $7: 72$ & 7.51 & 9.52 & $7 . \alpha_{4}$ & 73.9 \\
\hline \multirow[t]{2}{*}{$\mathbf{E}^{*}$} & oil & 7.52 & 7.51 & 22.1 & 10.35 & 85.7 \\
\hline & plate & 7.82 & 7.52 & 12.1 & 10.48 & 86.8 \\
\hline
\end{tabular}

\section{Effect of method of sample collection}

It has been reported by Hopkins, Howard, and Eisenberg (18) that when serum is equilibrated with 5 per cent $\mathrm{CO}_{2}-95$ per cent $\mathrm{O}_{2}$ to adjust $\mathrm{pH}$ before ultrafiltration, the method of collection of the blood is not particularly important. Prasad and Flink (19), on the other hand, considered the method of collection and equilibration of serum highly important.

Our findings are in agreement with those of Hopkins, Howard, and Eisenberg and are shown in Table I. Blood allowed to clot under oil and transferred without loss of $\mathrm{CO}_{2}$ gave results identical with those obtained when no special precautions were exercised, provided the apparatus was flushed with $\mathrm{CO}_{2}-\mathrm{O}_{2}$ mixture before the ultrafiltration procedure was carried out.

\section{Effect of duration of ultrafiltration on composition of ultrafiltrate}

Since ultrafiltration is a dynamic process and concentrates the serum proteins, a criticism frequently voiced is that the calcium concentration in the ultrafiltrate may not reflect the original conditions in the whole serum. This criticism may be shown to be invalid by the application of physical chemical principles to the finding of Marrack

\footnotetext{
${ }^{3}$ The thermodynamic dissociation constant of the calcium complex is

$$
\mathrm{K}=\left[\mathrm{Ca}^{++}\right] \cdot \frac{\left[\text { Prot}^{-}\right]}{[\mathrm{Ca} \text { Proteinate }]}
$$

where the quantities in the brackets are activities. According to this equation the ratio of bound to unbound protein is a function of the calcium ion activity in the sol-
}

and Thacker (26) and McLean and Hastings (22) that the relationship between calcium and serum proteins may be expressed by the simple equation: $\mathrm{Ca}^{++}+$Prot $^{=} \rightleftharpoons$ CaProteinate. ${ }^{3}$ Where a $1: 1$ relationship between the calcium and protein in the complex exists, these theoretical considerations show that the composition of the ultrafiltrate ution. In serum of ionic strength $0.15 \mathrm{M}$, the protein concentration is about $0.001 \mathrm{M}$ and is considered to contribute a negligible amount to the total ionic strength (27). Thus relatively large alterations in protein concentration must be produced before any change in ionic strength occurs. Chen and Neuman (24) showed that diffusible forms of calcium (calcium chloride, calcium citrate, and calcium versenate) in $0.15 \mathrm{M}$ sodium chloride move through a cellophane membrane at the same rate as water. Similar behavior during ultrafiltration of serum would then cause no change in the concentration of any diffusible ions in the free water of the bulk solution, an increase in the concentration of both forms of protein, but only a negligible change in ionic strength. Since the largest factor in the determination of activity coefficients is the ionic strength, the activity coefficients of all constituents in the remaining serum would remain essentially constant during the ultrafiltration process. Thus, with no change in activity coefficients, calcium ion concentration and the ratio of the two forms of protein do not change.

The above discussion would apply equally to any reaction involving a fixed number of one or more calcium ions with a single protein molecule. Thus

$$
\begin{aligned}
& \text { n } \mathrm{Ca}^{++}+\text {Prot } \rightleftharpoons \mathrm{Ca}_{\mathrm{n}} \text { Prot } \\
& \mathrm{K}=\left[\mathrm{Ca}^{++}\right]^{\mathrm{n}} \frac{[\text { Prot }]}{\left[\mathrm{Ca}_{\mathrm{n}} \text { Prot }\right]}
\end{aligned}
$$

The ultrafiltration procedure would not change the $\mathrm{Ca}^{++}$ concentration and the Prot/Can Prot ratio would remain constant although the concentrations of the two forms of protein change continuously. 
TABLE II

Successive samples during prolonged ultrafiltration. Patients with chronic renal disease and hypocalcemia

\begin{tabular}{|c|c|c|c|c|c|}
\hline \multirow[b]{2}{*}{ Sample } & \multirow[b]{2}{*}{$\begin{array}{c}\text { Untrafultration } \\
\text { temperature }\end{array}$} & \multirow[b]{2}{*}{ hours in } & \multicolumn{3}{|c|}{ SERTA CALCTUS } \\
\hline & & & Total & OItrafilterablo & Ontrapilterablo \\
\hline \multirow[t]{3}{*}{8} & $23^{\circ}$ & $0-4$ & 8.86 & 7.17 & 80.9 \\
\hline & $23^{\circ}$ & $4-7$ & 8.86 & 7.17 & 80.9 \\
\hline & $23^{\circ}$ & $7-20$ & 8.86 & 6.90 & 77.9 \\
\hline \multirow[t]{2}{*}{ R } & $36^{\circ}$ & $0-3$ & 5.58 & 3.81 & 68.3 \\
\hline & $36^{\circ}$ & $3-7$ & 5.58 & .3 .81 & 68.3 \\
\hline \multirow[t]{4}{*}{ C } & $23^{\circ}$ & $0-3$ & 7.45 & 5.72 & 76.7 \\
\hline & $23^{\circ}$ & $3-7$ & 7.45 & 5.72 & 76.7 \\
\hline & $36^{\circ}$ & $0-3$ & 7.45 & 5.04 & 67.7 \\
\hline & $36^{\circ}$ & $3-7$ & 7.45 & 5.17 & 69.4 \\
\hline
\end{tabular}

should be that of the non-protein portion of the original serum and should not change unless the ionic strength of the solution being ultrafiltered changes significantly during the process. These considerations were confirmed by collecting successive samples of ultrafiltrate during prolonged ultrafiltration of a single 3-ml. aliquot of serum and determining the calcium content of the samples.

TABLE III

Variabilityiof ultrafilterable calcium with $p H$

\begin{tabular}{|c|c|c|c|c|c|}
\hline \multirow[b]{2}{*}{ Samplo } & \multirow[b]{2}{*}{$\begin{array}{c}\text { Mtrafulitration } \\
\text { temperature }\end{array}$} & \multirow[b]{2}{*}{$\begin{array}{c}\text { OItrafiltrate } \\
\text { pH }\end{array}$} & \multicolumn{3}{|c|}{ SERUM CALCTUM } \\
\hline & & & Total & oltrafilterable & ${ }^{8}$ \\
\hline \multirow[t]{2}{*}{ B } & $36^{\circ}$ & 7.68 & 9.51 & 6.41 & 67.4 \\
\hline & $36^{\circ}$ & 8.22 & 9.51 & 5.28 & 55.6 \\
\hline \multirow[t]{2}{*}{ B } & $36^{\circ}$ & 6.35 & 9.40 & 8.05 & 86.6 \\
\hline & $36^{\circ}$ & 7.51 & 9.40 & 6.28 & 66.7 \\
\hline \multirow[t]{2}{*}{3} & $36^{\circ}$ & 6.35 & 9.27 & 8.60 & 91.5 \\
\hline & $36^{\circ}$ & 8.18 & 9.27 & 5.38 & 57.3 \\
\hline \multirow[t]{2}{*}{$*$} & $36^{\circ}$ & 7.68 & 11.57 & 8.36 & 72.2 \\
\hline & $36^{\circ}$ & 8.22 & 11.57 & 6.36 & 59.3 \\
\hline \multirow[t]{3}{*}{$\boldsymbol{F}$} & $23^{\circ}$ & 6.52 & 10.15 & 9.28 & 91.4 \\
\hline & $23^{\circ}$ & 7.63 & 10.15 & 7.76 & 76.4 \\
\hline & $23^{\circ}$ & 8.40 & 10.15 & 5.32 & 57.3 \\
\hline \multirow[t]{2}{*}{$s$} & $23^{\circ}$ & 7.56 & 9.69 & 7.48 & 75.7 \\
\hline & $23^{\circ}$ & 8.37 & 9.89 & 5.67 & 57.3 \\
\hline \multirow[t]{2}{*}{$\boldsymbol{m}$} & $10^{\circ}$ & 7.46 & 11.57 & 9.30 & 80.3 \\
\hline & $10^{\circ}$ & 8.4 & 21.57 & 8.13 & 70.3 \\
\hline
\end{tabular}


TABLE IV

Comparison of acid and carbon dioxide $p H$ adjustment. Uitrafitration temperature $23^{\circ} \mathrm{C}$

\begin{tabular}{|c|c|c|c|c|}
\hline \multirow{2}{*}{$\begin{array}{c}\text { Mothod } \\
\text { of } \\
\text { Adjustment }\end{array}$} & \multirow[b]{2}{*}{$\begin{array}{c}\text { Adjusted } \\
\text { pH }\end{array}$} & \multicolumn{3}{|c|}{ SERUA GRLCIUY } \\
\hline & & $\begin{array}{c}\text { Total } \\
\text { ags }\end{array}$ & 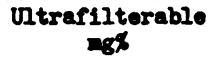 & $\mathbb{8}_{\text {Ultrafiltorable }}$ \\
\hline $5 \% \mathrm{CO}_{2}-958 \mathrm{O}_{2}$ & 7.55 & $8.14 *$ & 6.64 & 81.6 \\
\hline $100 \% \mathrm{CO}_{2}$ & 6.48 & $n$ & 7.58 & 93.2 \\
\hline Hjdrochlorie acid & 6.58 & " & 7.49 & 92.1 \\
\hline
\end{tabular}

The ultrafiltration apparatus was re-equilibrated with the $\mathrm{CO}_{2}-\mathrm{O}_{2}$ mixture after each $0.6-\mathrm{ml}$. sample was collected for analysis and the results are shown in Table II.

From an original sample of $3 \mathrm{ml}$. the collection of approximately $0.6 \mathrm{ml}$. of ultrafiltrate for calcium analysis will result in a reduction in volume of 20 per cent in the original serum or an increase in the concentration of protein of 25 per cent. In the first sample shown in the table the three successive $0.6-\mathrm{ml}$. aliquots of ultrafiltrate decreased the original serum volume to less than one-half of the original volume. Thus a large fraction of the serum may be ultrafiltered without an appreciable change in the composition of the ultrafiltrate, and the reduction in volume of the serum accompanying the usual ultrafiltration would not be expected to affect the results obtained.

\section{Effect of $p H$}

The literature contains conflicting information on this subject. Almost without exception, early

TABLE V

Effect of temperature on ultrafilterability of calcium

\begin{tabular}{|c|c|c|c|c|}
\hline \multirow[b]{2}{*}{ Sample } & \multirow[b]{2}{*}{$\begin{array}{c}\text { Untrafiltration } \\
\text { temperature }\end{array}$} & \multicolumn{3}{|c|}{ SERUM CALCIUM } \\
\hline & & $\begin{array}{c}\text { Total } \\
\text { mgl }\end{array}$ & $\begin{array}{c}\text { Untrafilterable } \\
\text { mg } \phi\end{array}$ & ${ }^{\$}$ UItrafilterable \\
\hline \multirow[t]{4}{*}{$\mathbf{J}$} & $3.5^{\circ}$ & 9.36 & 7.96 & 85.2 \\
\hline & 10 & 9.36 & 7.41 & 79.2 \\
\hline & 23 & 9.36 & 6.96 & 74.3 \\
\hline & 36 & 9.36 & 6.51 & 69.6 \\
\hline \multirow[t]{4}{*}{ B } & $3.5^{\circ}$ & 10.27 & 7.46 & 72.6 \\
\hline & 10 & 10.27 & 7.26 & 70.5 \\
\hline & 23 & 10.27 & 6.96 & 67.8 \\
\hline & 36 & 10.27 & 6.24 & 60.8 \\
\hline \multirow[t]{3}{*}{$\mathbf{R}$} & $10^{\circ}$ & 9.84 & 7.81 & 79.3 \\
\hline & 23 & 9.84 & 7.33 & 74.6 \\
\hline & 36 & 9.84 & 6.44 & 65.5 \\
\hline \multirow[t]{3}{*}{$\mathbf{I}$} & $10^{\circ}$ & 9.74 & 7.46 & 76.6 \\
\hline & 23 & 9.74 & 7.26 & 74.5 \\
\hline & 36 & 9.74 & 6.58 & 67.7 \\
\hline
\end{tabular}


workers took no special precautions to insure constancy of $\mathrm{pH}$ during the process of ultrafiltration. It has been reported $(2,3,10)$ that variations in $\mathrm{pH}$ during ultrafiltration have no effect on the results obtained although it was admitted that, on theoretical grounds, this was unexpected (10). In any event, rigid control of $\mathrm{pH}$ would have been difficult since the methods most frequently utilized (Greenberg-Gunther [10] and Moritz-Updegraff [6] ) had no adequate provision for maintaining a constant atmosphere to control $\mathrm{pH}$ throughout the entire ultrafiltration process (29). Recently, however, Hopkins, Howard, and Eisenberg (18), using the closed apparatus of Lavietes (28), reported a very definite effect of $\mathrm{pH}$ on the fraction of serum calcium appearing in the ultrafiltrate.
The apparatus used in the present study also controls the atmosphere rigidly during the filtration process and we have reinvestigated the problem. Our data, recorded in Table III, confirm the observation that the $\mathrm{pH}$ at which ultrafiltration is carried out affects significantly the fraction of calcium that is ultrafiltrable. Analysis of these data shows that the per cent of ultrafiltrable calcium changed from 1.5 to 2.5 per cent per $0.1 \mathrm{pH}$ unit in good agreement with values calculated from data previously reported $(26,18,30)$.

The lowering of $\mathrm{pH}$ was accomplished by equilibrating the serum in the ultrafiltration apparatus with 100 per cent $\mathrm{CO}_{2}$. The high $\mathrm{pH}$ 's were obtained by ultrafiltering serum with no carbon dioxide equilibration. Hopkins, Howard, and Eisen-

TABLE VI

Ultrafilterable calcium values for normal human serum at various temperatures. (All samples equitibrated with 5 per cent $\mathrm{CO}_{2}-95$ per cent before ultrafiltration)

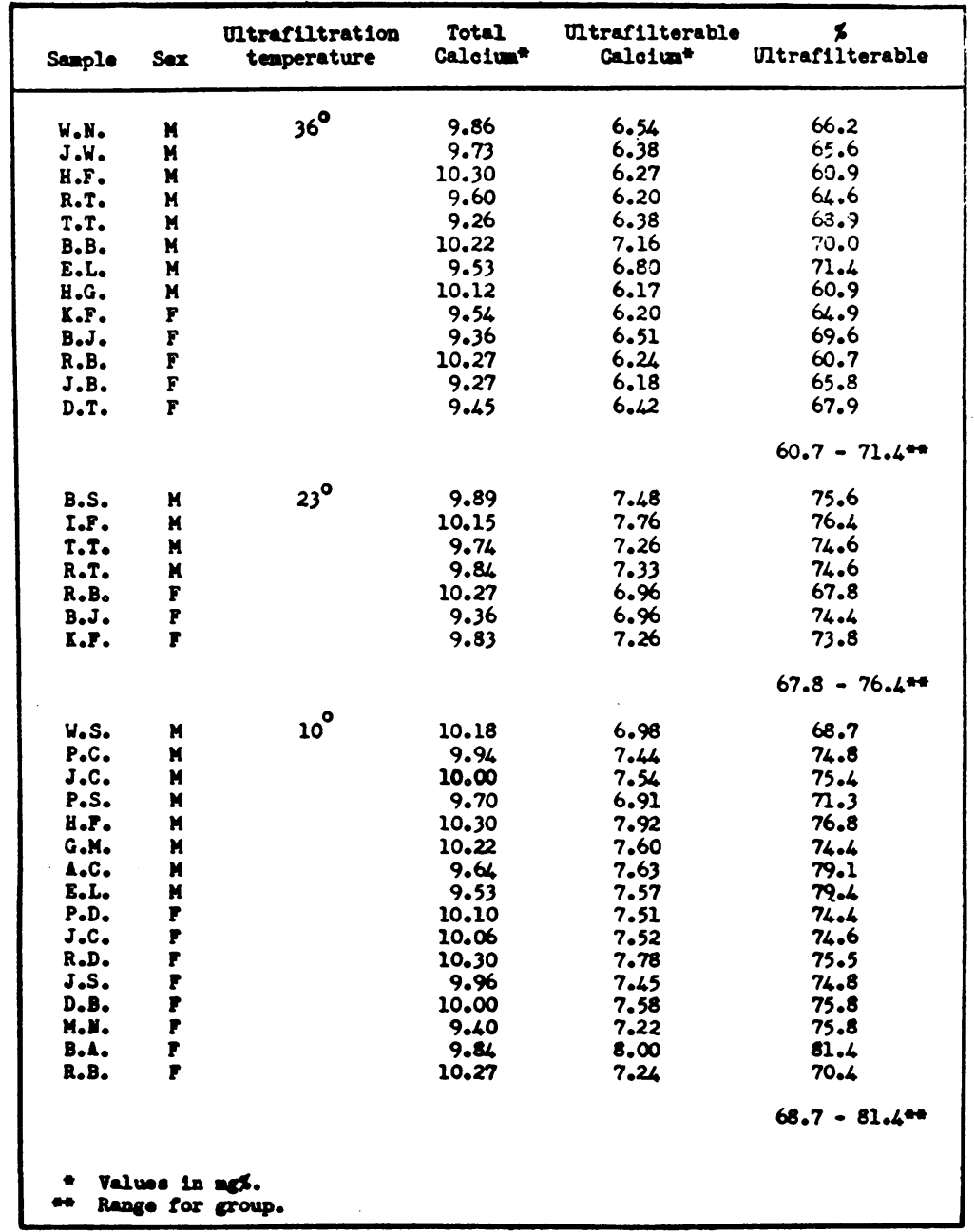


berg (18) altered $\mathrm{pH}$ by the addition of acid or alkali. It has been reported (19) that serum exposed to an excess of $\mathrm{CO}_{2}$ showed a significant increase in ultrafiltrable calcium even though the $\mathrm{pH}$ was kept in the physiological range. This increase was thought to represent an artifact owing to the high concentration of carbonic acid. As shown in Table IV, however, $\mathrm{pH}$ seems to be the important factor in altering ultrafiltrability of calcium rather than the method of attaining it. The carbon dioxide content of the serum would be quite different if acid were used to lower the $\mathrm{pH}$ instead of carbon dioxide, but the ultrafiltrability of the calcium is approximately the same. This substantiates earlier findings (31) that the carbonate binding of calcium is not very strong and contributes only a small amount to the non-protein bound calcium in serum.

\section{Effect of temperature}

The information concerning any effect of temperature on the ultrafiltrability of calcium is sparse. Among more recent workers, Hopkins, Howard, and Eisenberg (18) have reported that there is no change in the range from room temperature to $36^{\circ} \mathrm{C}$. Consequently, all their reported data were obtained at room temperature as were the data of virtually all the earlier workers (Table VIII). Because of the convenience of using a refrigerated centrifuge to maintain a constant temperature, much of the early data in our work on normal serum were obtained at a temperature of $10^{\circ} \mathrm{C}$. However, a number of normal values for ultrafiltrable calcium obtained at physiological temperature were noted to be considerably lower than those at $10^{\circ} \mathrm{C}$. This suggested the need for investigating the effect of temperature. To reduce the variables to a minimum, ultrafiltrations were carried out simultaneously at several temperatures using serum obtained from one individual. The results are shown in Table $\mathrm{V}$. A large number of other samples were ultrafiltered at $10^{\circ} \mathrm{C}$ and at $36^{\circ} \mathrm{C}$ and all the results indicated that the percentage of ultrafiltrable calcium was considerably higher at the lower temperature. The temperature coefficient is approximately 0.5 per cent per degree centigrade.

\section{Normal values for human serum}

Our individual values for normal healthy young men and women are recorded in Table VI. The

TABLE VII

Repeated determinations of ultrafitterable calcium in normal individuals. Ultrafitration temperature $36^{\circ} \mathrm{C}$

\begin{tabular}{|c|c|c|c|c|}
\hline Subject & Date & $\begin{array}{l}\text { Total } \\
\text { Calcium* }\end{array}$ & $\begin{array}{l}\text { Untrafilterable } \\
\text { Calcium }\end{array}$ & $\$_{\text {Ultrafilterable }}^{\$}$ \\
\hline T.T. $(\operatorname{mal} 0)$ & $\begin{array}{l}1 / 12 / 56 \\
1 / 19 / 56 \\
2 / 7 / 56 \\
3 / 22 / 56 \\
5 / 10 / 56\end{array}$ & $\begin{array}{r}9.26 \\
9.20 \\
9.74 \\
9.77 \\
10.07\end{array}$ & $\begin{array}{l}6.38 \\
6.27 \\
6.58 \\
6.64 \\
7.13\end{array}$ & $\begin{array}{l}68.9 \\
68.1 \\
67.6 \\
68.5 \\
70.8\end{array}$ \\
\hline R.T. (malo) & $\begin{array}{l}1 / 17 / 56 \\
1 / 27 / 56 \\
2 / 7 / 56 \\
3 / 22 / 56\end{array}$ & $\begin{array}{l}9.60 \\
9.51 \\
9.84 \\
9.96\end{array}$ & $\begin{array}{l}6.20 \\
6.41 \\
6.44 \\
6.51\end{array}$ & $\begin{array}{l}64.6 \\
67.4 \\
65.5 \\
65.3\end{array}$ \\
\hline B.J. (fenalo) & $\begin{array}{l}2 / 9 / 56 \\
3 / 20 / 56 \\
4 / 5 / 56 \\
4 / 9 / 56 \\
5 / 4 / 56 \\
5 / 8 / 56 \\
5 / 31 / 56 \\
7 / 6 / 56\end{array}$ & $\begin{array}{r}9.36 \\
10.02 \\
9.52 \\
9.79 \\
10.00 \\
9.73 \\
9.40 \\
9.86\end{array}$ & $\begin{array}{l}6.51 \\
6.35 \\
6.30 \\
6.94 \\
6.90 \\
6.85 \\
6.18 \\
6.44\end{array}$ & $\begin{array}{l}69.6 \\
63.3 \\
66.2 \\
70.3 \\
69.0 \\
70.3 \\
66.7 \\
65.3\end{array}$ \\
\hline
\end{tabular}


TABLE VIII

The per cent of ultrafilterable or diffusible calcium in normal human serum as determined by previous authors

\begin{tabular}{|c|c|c|c|c|c|c|}
\hline Autbor & Iear & Mothod & $\begin{array}{c}\mathrm{pH} \\
\text { Control }\end{array}$ & Temp. & $\begin{array}{l}\text { No. of } \\
\text { Dotns. }\end{array}$ & $\underset{8}{\text { Range }}$ \\
\hline 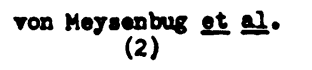 & 1921 & Componsation. Dialyeis & Yos & Roca & 7 & $67-73$ \\
\hline $\begin{array}{l}\text { Nouhauson and P1nous } \\
\text { (3) }\end{array}$ & 1923 & $\begin{array}{l}\text { U1trafiltration with } \\
\text { positive Hg pressure }\end{array}$ & No & Room & $?$ & $40-50$ \\
\hline $\begin{array}{l}\text { Rosa and Mollt } \\
\text { (4) }\end{array}$ & 1925 & Componsation Dialyeis & Yes & Roow & 4 & $64-69$ \\
\hline Kirk and $\mathrm{King}$ & 1926 & $\begin{array}{l}\text { Ultraflitration with } \\
\text { positive } \mathrm{H}_{2} \mathrm{O} \text { pressure }\end{array}$ & No & $37^{\circ} \mathrm{C}$ & 5 & $56-81 *$ \\
\hline $\begin{array}{l}\text { Updegraff } \\
(6)^{t}\end{array}$ & 1926 & $\begin{array}{l}\text { Morits (37) (combined } \\
\text { ultrafiltration and } \\
\text { compensation dialje1s) }\end{array}$ & No & Roow & 19 & $41-54$ \\
\hline Ifu (7) & 1927 & Mor1ts-Updograff & No & Room & 10 & $42-58$ \\
\hline Herte (8) & 1927 & $\begin{array}{l}\text { Ultrafiltration with } \\
\text { positive } N_{2} \text { prossure }\end{array}$ & No & Room & 4 & $43-61$ \\
\hline Snell (9) & 1930 & Mor1tz-Opdegraff & No & Room & $?$ & $45-60$ \\
\hline $\begin{array}{l}\text { Greonborg and Guntber } \\
\text { (10) }\end{array}$ & 1930 & $\begin{array}{l}\text { Untrafiltration with } \\
\text { Degative pressure }\end{array}$ & No & Room & 24 & $42-68+4$ \\
\hline $\begin{array}{l}\text { Mocasee and Watehors } \\
\text { (II) }\end{array}$ & 1931 & Greonborg-Gunther & No & Roore & 15 & $44-66$ \\
\hline $\begin{array}{l}\text { Intchorn and Mocance } \\
\text { (12) }\end{array}$ & 1932 & Greenberg-Gunther & No & Room & 6 & $45-59$ \\
\hline N1cholas (13) & 1932 & $\begin{array}{l}\text { Ultrafiltration with } \\
\text { posit1fe } \mathrm{N}_{2} \text { pressure }\end{array}$ & No & Roow & 13 & $60-67$ \\
\hline $\begin{array}{l}\text { Herbert (u) } \\
\text { (14) }\end{array}$ & 1933 & Greenbore-Guntber & No & Rocen & 7 & $48-58$ \\
\hline $\begin{array}{l}\text { Benjento and Hese } \\
\text { (15) }\end{array}$ & 1933 & $\begin{array}{l}\text { Ultrafiltration with } \\
\text { positive alr pressure }\end{array}$ & No & Room & $21 * n$ & 52 \\
\hline Morleon $\frac{\text { t }}{(16)}$ al. & 1938 & Mor1ts-Updegraff & No & Roca & 8 & $43-62$ \\
\hline $\left.\operatorname{Aming} \frac{t}{(17)}\right)^{a}$ & 1948 & Mor1ts-Updegrafr & No & Room & 20 & 51 \\
\hline Hopkine $\frac{2 t}{(18)}$ 일. & 1952 & $\begin{array}{l}\text { Laviotoo (28) (ultre- } \\
\text { flitration over He) }\end{array}$ & Yee & Rocan & 8 & $65-75$ \\
\hline $\begin{array}{l}\text { Praced and Filnk } \\
\text { (19) }\end{array}$ & 1955 & $\begin{array}{l}\text { Ultrafiltration with } \\
\text { oontrifugal foroo }\end{array}$ & Yoe & Room & $?$ & $\begin{array}{l}47-56 \\
57-72\end{array}$ \\
\hline \multicolumn{7}{|c|}{ 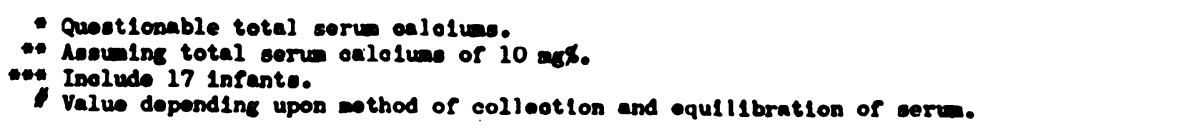 } \\
\hline
\end{tabular}

mean values for the per cent of ultrafiltrable calcium determined at $36^{\circ} \mathrm{C}$ is 65.9 per cent while at $10^{\circ} \mathrm{C}$ it is 75.2 per cent. At $23^{\circ} \mathrm{C}$ the mean is 73.9 per cent but we believe this is erroneously high due to the small number of samples determined at this temperature. No sex difference was observed. In Table VII are recorded determinations of ultrafiltrable calcium on three normal individuals, extending over a period of several months. It can be seen that fluctuations occurred over the period and these were all within the normal range (Table VI). Repeated determinations 
of ultrafiltrable calcium in human subjects during a single day, however, are remarkably constant (32).

In Table VIII is recorded the per cent ultrafiltrability or diffusibility of the calcium of normal human serum calculated from the data of previous authors. It is immediately apparent that, with the exception of von Meysenbug, Pappenheimer, Zuker, and Murray (2), Rona and Melli (4), Nicholas (13) and Kirk and King (5), earlier workers obtained results significantly lower than our values and those of the two most recent authors $(18,19)$.

From the previous discussion on the effect of $\mathrm{pH}$ on the quantity of ultrafiltrable calcium it seems most probable that failure to control the $\mathrm{pH}$ during ultrafiltration was predominantly responsible for the consistently lower values obtained by these early workers. In this connection, it is of interest that the results of von Meysenbug, Pappenheimer, Zuker, and Murray (2) and of Rona and Melli (4) were obtained by compensation dialysis in a closed system where the $\mathrm{pH}$ was probably maintained constant throughout the procedure. The original Rona and Takahashi investigations of 1911 (1) were done by essentially the same method. Their value for the diffusible serum calcium of various domestic animals was between 65 per cent and 75 per cent! Nicholas (13) and Kirk and King (5) took no special precautions regarding $\mathrm{pH}$ control but the apparatus they used was closed during the entire filtration and positive pressure was maintained over the serum with nitrogen or air.

\section{DISCUSSION}

Our data indicate that, with a normal total serum calcium concentration of about $10 \mathrm{mg}$. per cent, 6 to $7 \mathrm{mg}$. per cent of this calcium is ultrafiltrable. McLean and Hastings (22), by their frog heart technique, concluded that about $1.3 \mathrm{mM}$ per L. (5.2 mg. per cent) of "ionic" calcium exists in normal serum. Calculations based on the actual normal serum concentrations of citrate, phosphate, and bicarbonate, activity coefficients, and the reported pK's of the calcium complexes of these anions reveal that about $0.3 \mathrm{mM}$ per $\mathrm{L}$. (1.2 mg. per cent) of calcium exists in normal serum in the form of these known complexes (33). The sum of these two values, $6.4 \mathrm{mg}$. per cent, is remarkably similar to the mean value of our experimentally determined range for normal total ultrafiltrable calcium and closely approaches the value for "biologically active" calcium suggested by the data of Yendt, Connor, and Howard (21).

Variations in the $\mathrm{pH}$ of the blood in human beings in vivo seldom extend more than $0.2 \mathrm{pH}$ units above or below the 7.35 to 7.40 range even in pathological states involving alterations in acidbase balance. From our data this would mean only a minor alteration in the actual quantity of ultrafiltrable calcium, well within the 10 per cent range found in normal human subjects. In acute conditions, however, such as hyperventilation tetany, a sudden minor shift in the quantity of available calcium may well be highly important. It has been reported that in hyperventilation tetany, total serum calcium and total ultrafiltrable calcium do not change significantly $(34,35)$. However, the actual alterations in the quantity of calcium involved due to $\mathrm{pH}$ changes in the physiological range are small enough so as to lie near or within the limits of accuracy of all the experimental methods for estimating total and ultrafiltrable calcium.

The observed effect of temperature on the quantity of ultrafiltrable calcium in human serum was somewhat surprising. Most complexes become more stable at lower temperature, but we found that more calcium was ultrafiltrable as the temperature at which the procedure was carried out was decreased.

The only bits of corroborative evidence for this temperature effect we were able to find were in the work of McLean and Hastings (22), Lavietes (28), and Marrack and Thacker (26). In 1926, the latter authors, by dialysis of protein solutions at room temperature and at $37^{\circ} \mathrm{C}$, concluded that values for non-diffusible calcium of serum would be lower if the determinations were made at room temperature. Lavietes, in 1937, described his anaerobic ultrafiltration apparatus and referred to the fact that the quantity of calcium filtered varied with temperature but no data were given. McLean and Hastings noted that the amount of "ionic calcium" was about $0.15 \mathrm{mM}$ per L. ( $0.6 \mathrm{mg}$. per cent) higher at $15^{\circ} \mathrm{C}$ than at $25^{\circ} \mathrm{C}$. Although questioning the significance of this observation, they did calculate by extrapolation that calcium ion concentrations would be $0.8 \mathrm{mg}$. per cent lower 
at $38^{\circ} \mathrm{C}$ than those observed at room temperature if this temperature effect were real. That is, with an average normal serum calcium of $10 \mathrm{mg}$. per cent the concentration would be about 8 per cent lower. This value agrees very well with our data on normal values at different temperatures recorded in Table V.

The exact mechanism responsible for this temperature effect is not clear. It may be that in the binding of calcium to protein a weaker bond is obtained at lower temperatures, but Katz and Klotz (36) claim that the binding of calcium to bovine serum albumin is independent of temperature from $0^{\circ} \mathrm{C}$ to $25^{\circ} \mathrm{C}$. A change in $\mathrm{pH}$ is apparently not involved. We have found that the $\mathrm{pH}$ in an aliquot of serum measured at room temperature, after 5 per cent $\mathrm{CO}_{2}-95$ per cent $\mathrm{O}_{2}$ equilibration at that temperature, did not change significantly when the $\mathrm{pH}$ was remeasured after heating to $36^{\circ} \mathrm{C}$.

One other possible explanation for the phenomenon of decreased protein-bound calcium at the lower temperatures is suggested when one considers the binding of calcium by other anions in serum such as citrate, phosphate, and bicarbonate. The relationship between the latter and ionic calcium and calcium bound to protein can be expressed by the equation $\mathrm{CaX} \rightleftharpoons \mathrm{Ca}^{++} \rightleftharpoons \mathrm{CaProt}$ where $\mathrm{X}$ refers to these ultrafiltrable anionic complexers of calcium. If the temperature coefficients of the filtrable complexes of calcium were greater than those of the protein complexes, the net effect of a lowering of temperature would be to have more of the calcium in the form of these ionic complexes and a resultant increase in ultrafiltrable calcium as found. The data of Katz and Klotz (36), who found that the binding of calcium ions by bovine serum albumin was independent of temperature, lend support to this explanation. If this explanation is correct, a net decrease in the actual ionic form of calcium would occur as the ultrafiltration temperature is lowered although total ultrafiltrable calcium increases. That is, more of the calcium ultrafiltered would be in an associated form. Thus, it would appear that the McLean and Hastings frog heart method, which also responds to a lowering of temperature with an apparent increase in "ionic" calcium, measures more than just the ionic calcium in the test solution. It is clear that further work with pure pro- teins is necessary to elucidate the exact nature of the temperature effect observed.

\section{SUMMARY}

1. A new simple ultrafiltration apparatus is described and the procedure for the ultrafiltration of human serum is outlined.

2. The importance of the method of sample collection, duration of filtration, $\mathrm{pH}$ and temperature was investigated. The ultrafiltration results were affected considerably by $\mathrm{pH}$ and temperature.

3. For healthy human subjects, the range for ultrafiltrable calcium at physiological $\mathrm{pH}$ and temperature was found to be 60 to 70 per cent of the total serum calcium. The results of previous authors are reviewed and compared with the present findings.

4. The quantitative distribution of the various calcium fractions in human serum and the significance of the observed effect of $\mathrm{pH}$ and temperature on the ultrafiltrability of calcium are discussed.

\section{REFERENCES}

1. Rona, P., and Takahashi, D., Uber das Verhalten des Calciums im Serum und über den Gehalt der Blutkörperchen an Calcium. Biochem. Ztschr., 1911, $31,336$.

2. von Meysenbug, L., Pappenheimer, A. M., Zuker, T. F., and Murray, M. F., The diffusible calcium of blood serum. I. A method for its determination. J. Biol. Chem., 1921, 47, 529.

3. Neuhausen, B. S., and Pincus, J. B., A study of the condition of several inorganic constituents of serum by means of ultrafiltration. J. Biol. Chem., 1923, 57, 99.

4. Rona, P., and Melli, G., Beitrag zur Frage der Ionenverteilung im Blutserum. III. Biochem. Ztschr., 1925, 166, 242.

5. Kirk, P. L., and King, C. G., Calcium distribution in blood. J. Lab. \& Clin. Med., 1926, 11, 928.

6. Updegraff, H., Greenberg, D. M., and Clark, G. W., A study of the distribution of the diffusible and non-diffusible calcium in the blood sera of normal animals. J. Biol. Chem., 1926, 71, 87.

7. Lui, S.-H., The partition of serum calcium into diffusible and non-diffusible portions. Chinese $J$. Physiol., 1927, 1, 331.

8. Hertz, W., Der ultrafiltrierbare Anteil des Serumkalkes. Ztschr. f. Kinderh., 1929, 47, 215.

9. Snell, A. M., The diffusibility of the calcium in the blood serum under normal and pathologic conditions. Proc. Staff Meet., Mayo Clinic, 1930, 5, 17.

10. Greenberg, D. M., and Gunther, L., On the determination of diffusible and non-diffusible serum calcium. J. Biol. Chem., 1930, 85, 491. 
11. McCance, R. A., and Watchorn, E., Inorganic constituents of cerebrospinal fluid. I. Calcium and magnesium. Quart. J. Med., 1931, 24, 371.

12. Watchorn, E., and McCance, R. A., Inorganic constituents of cerebro spinal fluid. II. The ultrafiltration of calcium and magnesium from human sera. Biochem. J., 1932, 26, 54.

13. Nicholas, H. O., Diffusible serum calcium by high pressure ultrafiltration. J. Biol. Chem., 1932, 97, 457.

14. Herbert, F. K., The total and diffusible calcium of serum and the calcium of cerebrospinal fluid in human cases of hypocalcaemia and hypercalcaemia. Biochem. J., 1933, $27,1978$.

15. Benjamin, H. R., and Hess, A. F., The forms of the calcium and inorganic phosphorus in human and animal sera. I. Normal, rachitic, hypercalcemic, and other conditions. J. Biol. Chem., 1933, 100, 27.

16. Morrison, R. S., McLean, R., and Jackson, E. B., Observations on the relation between ionized and total calcium in normal and abnormal sera and their ultrafiltrates. J. Biol. Chem., 1938, 122, 439.

17. Anning, S. T., Dawson, J., Dolby, D. E., and Ingram, J. T., The toxic effects of calciferol. Quart. J. Med., 1948, n.s. 17, 203.

18. Hopkins, T., Howard, J. E., and Eisenberg, H., U1trafiltration studies on calcium and phosphorus in human serum. Bull. Johns Hopkins Hosp., 1952, 91, 1.

19. Prasad, A., and Flink, E. B., The effect of carbon dioxide on the concentration of calcium in ultrafiltrate of serum obtained by centrifugation. $\mathrm{J}$. Clin. Invest., 1955, 34, 957.

20. McLean, F. C., and Urist, M. R., Bone; An Introduction to the Physiology of Skeletal Tissue, Chicago, Univ. of Chicago Press, 1955.

21. Yendt, E. R., Connor, T. B., and Howard, J. E., In vitro calcification of rachitic rat cartilage in normal and pathological human sera with some observations on the pathogenesis of renal rickets. Bull. Johns Hopkins Hosp., 1955, 96, 1.

22. McLean, F. C., and Hastings, A. B., The state of calcium in the fluids of the body. I. The conditions affecting the ionization of calcium. J. Biol. Chem., 1935, 108, 285.

23. Toribara, T. Y., Centrifuge type of ultrafiltration apparatus. Anal. Chem., 1953, 25, 1286.
24. Chen, P. S., Jr., and Neuman, W. F., Renal excretion of calcium by the dog. Am. J. Physiol., 1955, $180,623$.

25. Toribara, T. Y., Dewey, P. A., and Warner, H., Flame photometric determination of calcium in biological material. III. Effect of low level impurities from the calcium oxalate precipitation. Anal. Chem., 1957, 29, 540.

26. Marrack, J., and Thacker, G., The state of calcium in body fluids. Biochem. J., 1926, 20, 580.

27. Cohn, E. J., and Edsall, J. T., Proteins, Amino Acids and Peptides As Ions and Dipolar Ions. New York, Reinhold, 1943, p. 456.

28. Lavietes, P. H., Anaerobic ultrafiltration. J. Biol. Chem., 1937, 120, 267.

29. Smith, R. G., Non-diffusible serum-calcium at various calcium, phosphate and hydrogen ion concentrations. Biochem. J., 1934, 28, 1615.

30. Dillman, L. M., and Visscher, M. B., The calcium content of the ultrafiltrates of plasma and the influence of changes in hydrogen and bicarbonate ion concentrations upon it. J. Biol. Chem., 1933, 103, 791.

31. Neuman, W. F., Morrow, P. E., Toribara, T. Y., Casarett, L. J., Mulryan, B. J., and Hodge, H. C., Evidence for complex ion formation in the calcium bicarbonate system. J. Biol. Chem., 1956, 219, 551.

32. Terepka, A. R., Toribara, T. Y., and Dewey, P. A., The ultrafiltrable calcium of human serum. II. Variations in disease states and under experimental conditions. (In preparation.)

33. Neuman, W. F., and Neuman, M. W., The Chemical Dynamics of Bone Mineral, Univ of Chicago Press, In press.

34. Gunther, L., and Greenberg, D. M., The diffusible calcium of the blood stream in tetany. Arch. Int. Med., 1931, 47, 660.

35. McCance, R. A., Spontaneous overbreathing tetany. Quart. J. Med., 1932, n.s. 1, 247.

36. Katz, S., and Klotz, I. M., Interactions of calcium with serum albumin. Arch. Biochem. \& Biophys., 1953, 44, 351.

37. Moritz, A. R., The effect of ultra-violet irradiation on the state of serum calcium. J. Biol. Chem., 1925, 64, 81. 